\title{
Dust storm simulation over Iran using HYSPLIT
}

\author{
Khosro Ashrafi', Majid Shafiepour-Motlagh ${ }^{1}$, Alireza Aslemand ${ }^{1 *}$ and Sarmad Ghader ${ }^{2}$
}

\begin{abstract}
Particulate matters have detrimental effects on human health, environment and economic. This pollutant may emit from anthropogenic or natural sources. On global scale, main proportion of natural particulate matter release to the atmosphere because of wind erosion from arid and semi-arid regions. Recently, the amount of dust coming from Arabian countries has dramatically increased, especially dust storms that are affecting western and even central parts of Iran. This phenomenon has caused a lot of environmental problems. Dust source identification and trajectory simulation using numerical techniques are the main aims of this study. HYSPLIT (Hybrid Single Particle Lagrangian Integrated Trajectory) model dust module and trajectory simulation are utilized in this research and two case studies are investigated (in May and June 2010). The base of the HYSPLIT dust module is the PM10 dust storm emission algorithm for desert land use. This methodology is applied to estimate hotspots and trajectories. Due to the results, dust storms started on May 17th and June 7th because of high wind shear $(>8.5 \mathrm{~m} / \mathrm{s})$ from the western Syrian Desert. The source region limited to $32.50^{\circ} \mathrm{N}$ to $33.80^{\circ} \mathrm{N}$ and $38.00{ }^{\circ} \mathrm{E}$ to $38.80^{\circ} \mathrm{E}$ coordinates. Dust plumes lifted and dispersed towards the east and southeast of the sources and reached Ahvaz on May 18th and June 8th. The average of PM10 concentration in these dates reached 625 and $494 \frac{\mathrm{\mu g}}{\mathrm{m}^{3}}$ on Ahvaz monitoring stations, respectively. Moreover, the results gained from the model for dust motion simulation are similar to the MODIS satellite images.
\end{abstract}

Keywords: Dust storms, Dust sources, Trajectory, PM10, HYSPLIT, MODIS satellite images

\section{Introduction}

Dust storms and wildfires in natural resources can be the considerable sources of suspension dust [1]. On global scale, most of the dust emission comes from arid and semiarid areas [2]. The main dust source areas are located in arid climates (with annual rainfall under 200-250 mm) in the so-called 'dust belt' [3]. The 'dust belt' extends from the west coast of North Africa, the Middle East, central and south Asia to China (Figure 1) [4].

There are many drawbacks with the dust phenomenon such as environmental, socio-economic, human health, climate and microclimate problems [6]. Some of these issues are discussed as follows.

Wind-blown dust is an effective factor for the transport of pathogens and pollutants $[7,8]$ and also can influence air quality downwind of dust source regions by reducing visibility, soiling property and causing illnesses $[9,10]$. Inhalation of dust particles can cause heart beat irregularities, heart attacks and respiratory problems,

\footnotetext{
* Correspondence: aaslemand@ut.ac.ir

${ }^{1}$ Graduate Faculty of Environment, University of Tehran, Tehran, Iran

Full list of author information is available at the end of the article
}

severe and chronic headaches, severe allergies and skin diseases [11].

Particles such as mineral dust, by absorbing ultraviolet radiation can inhibit smog production, having profound implications in the control of air pollution in urban areas [12]. Furthermore, the interactions between windblown dust and anthropogenic pollutants aggravate the generation of secondary aerosols [13].

Dust particles have a significant effect on climate, acting both directly (by scattering and absorbing radiation) and indirectly (by changing the optical properties of clouds) on the Earth's radiation balance [14]. Absorption and scattering of solar radiation caused by dust events may affect air temperatures [15]. In another way Dust fertilization (including iron and phosphorus) of poor nutrient marine environments can increase formation of phytoplankton and can influence the global cycle of carbon [16].

Different Techniques have been developed to identify dust hotspots and pathways. Numerical modeling, trajectory analysis, Remote sensing and satellite imagery, dust observations and metrological data analysis, mineral 


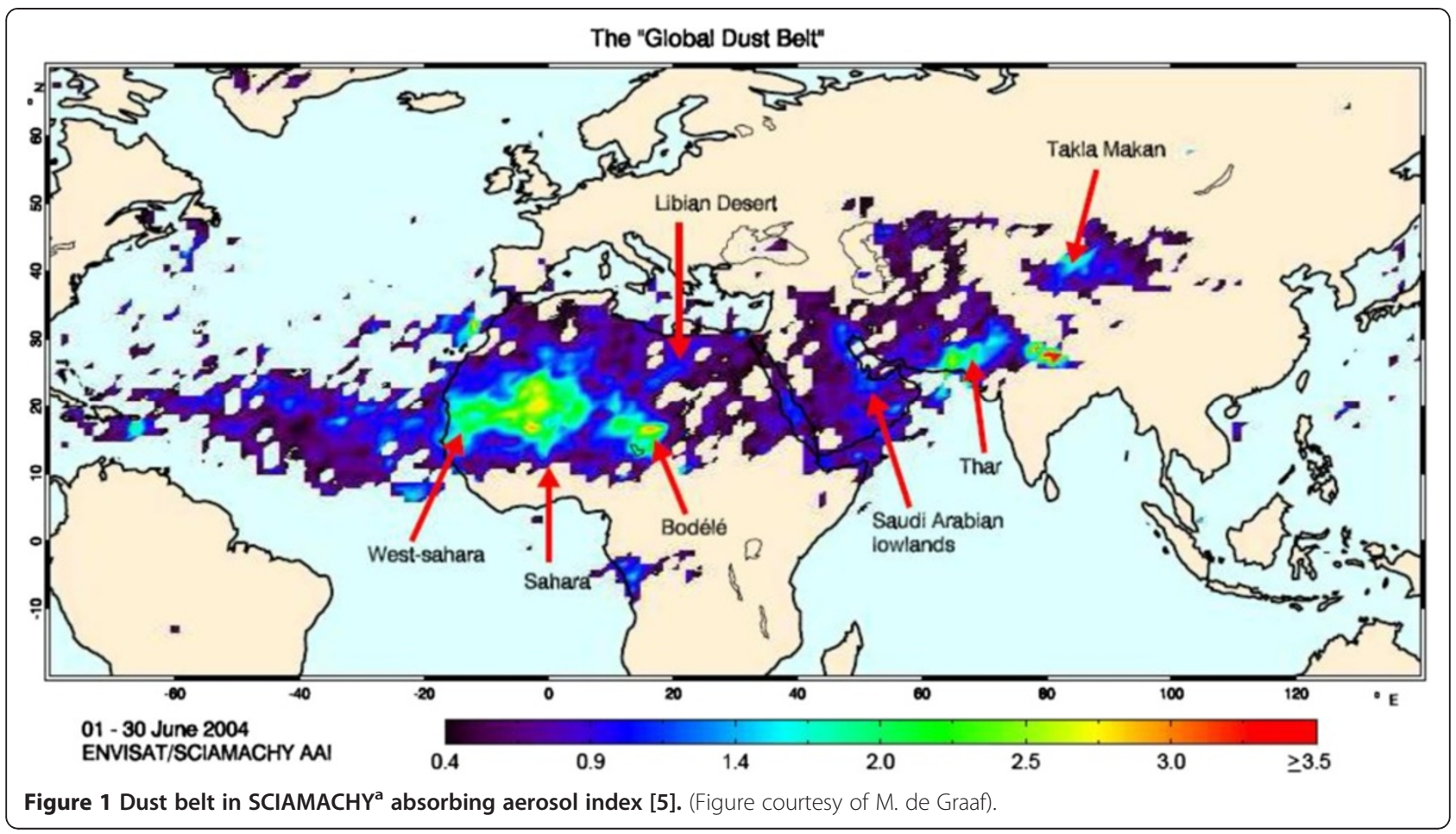

tracers and geological models can be applied as the principal tools used to research dust events [4,6,17-20].

In Iran a few studies have been carried out to determine dust sources, trajectories, contribution of dust to urban $\mathrm{PM}_{10}$ concentrations and temporal and spatial coverage of dust by using modeling techniques [21]. It should be mentioned that most of the conducted studies on these issues used satellite images and meteorological data analysis [22,23]. Most of the Dust storms in Iran are coming from the western and southern neighboring

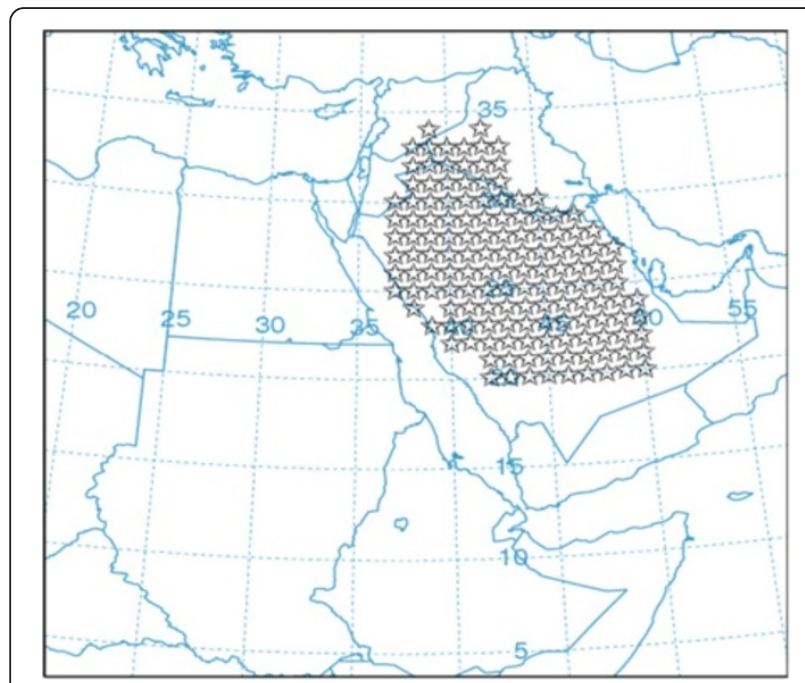

Figure 2 Dust sources regions defined in HYSPLIT dust module. countries and they affect western and central regions of Iran [6].

In this research, the most high risk city of Iran namely Ahvaz, is chosen as the case study. According to WHO database [24], Ahvaz with $372 \frac{\mu \mathrm{g}}{\mathrm{m}^{3}}$ annual mean of concentration of particulate matter is the first polluted city in the world. Finding the dust sources and the trajectories which cause the dust in Iran (specially the cities of Ahvaz and Tehran) has a significant importance. Therefore, this research uses numerical modeling techniques to study meteorological parameters, sources and trajectories of suspended particles of dust storms from wind erosions events. Surly, the results aim to control and reduce the amount of pollutions.

Table $1 \mathrm{PM}_{10}$ concentrations in Ahvaz air quality stations $\left(\frac{\mu g}{m^{3}}\right)$

\begin{tabular}{cccc}
\hline $\begin{array}{c}\text { Date of dust } \\
\text { event }\end{array}$ & $\begin{array}{c}\text { Environment dept. } \\
\text { station }\end{array}$ & $\begin{array}{c}\text { Meteorology office } \\
\text { station }\end{array}$ & $\begin{array}{c}\text { Naderi } \\
\text { station }\end{array}$ \\
\hline 17-May & 128 & 88 & 167 \\
18-May & 497 & 483 & 508 \\
19-May & 339 & 383 & 383 \\
20-May & 438 & 508 & 508 \\
7-Jun & 275 & 817 & 100 \\
8-Jun & 683 & 1100 & 100 \\
9-Jun & 215 & 204 & 33 \\
10-Jun & 266 & 254 & 158 \\
\hline
\end{tabular}




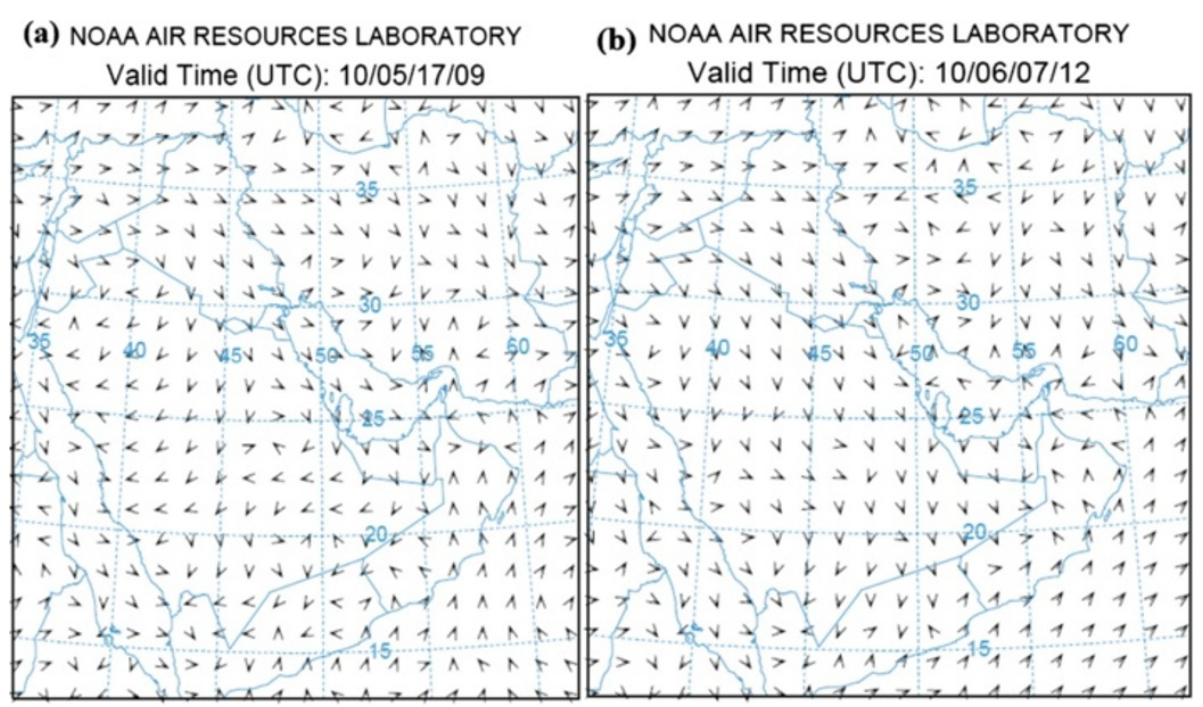

Figure 3 Wind fields over study area at the time of dust injection starting on (a) May 17th and (b) June 7th.

\section{Materials and methods}

\section{Study area}

Study area for dust injection to the atmosphere investigated using HYSPLIT $^{\mathrm{b}}$ model including parts of Saudi Arabia, Iraq, Syria and Jordan. This area limited to $20^{\circ} \mathrm{N}-36.30^{\circ} \mathrm{N}$ and $37^{\circ} \mathrm{E}-50^{\circ} \mathrm{E}$ coordinates. Only desert land-use areas participate in the dust module and model omits the other land uses automatically by definition of this algorithm. Figure 2 shows the desert land-use considered for dust emission in the present study.

\section{HYSPLIT model description}

The HYSPLIT model uses puff or particle approaches to compute trajectories, complex dispersion and deposition. The model computation method is a combination of Eulerian (concentrations are calculated for each grid cell using integration of pollutant fluxes at every grid cell interface due to advection and diffusion) and Lagrangian (concentrations are computed by summing the contribution of each pollutant "puff" that is advected through the grid cell as represented by its trajectory) approaches.

The model utilizes meshed meteorological data on one of three conformal map projections (Polar, Lambert and

Table 2 Surface metrological parameters for two dust events in source areas

\begin{tabular}{|c|c|c|c|c|c|c|}
\hline Parameter & $\begin{array}{c}\text { Pressure } \\
\text { (hpa) }\end{array}$ & $\begin{array}{c}\text { Surface } \\
\text { height }(\mathrm{m})\end{array}$ & $\begin{array}{l}\text { Temperature } \\
\text { at } 2 \mathrm{~m} \mathrm{(c)}\end{array}$ & $\begin{array}{l}\mathrm{U} \text { wind }^{\mathrm{d}} \\
\text { at } 10 \mathrm{~m} \\
(\mathrm{~m} / \mathrm{s})\end{array}$ & $\begin{array}{c}\mathrm{V} \text { wind }^{\mathrm{e}} \\
\text { at } 10 \\
\mathrm{~m}(\mathrm{~m} / \mathrm{s})\end{array}$ & $\begin{array}{c}\text { PBLH } \\
\text { (m) }\end{array}$ \\
\hline May event & 936 & 676 & 34.4 & 8.6 & 0.75 & 2063 \\
\hline June event & 925 & 740 & 31.7 & 10.1 & 2.2 & 257 \\
\hline
\end{tabular}

Mercator). The dispersion model requires meteorological data fields that can be obtained from archives or from forecast model outputs and the datasets should be formatted for input to HYSPLIT $[25,26]$.

The accuracy of the model is considerably dependent on the meteorological data resolution [27], For this study, we used GDAS ${ }^{\mathrm{c}}$ meteorological data provided by U.S NOAA.

In HYSPLIT dust module, $\mathrm{PM}_{10}$ dust injections are estimated using as mass source algorithm [28].

$$
F=K \frac{\rho}{g} u_{*}\left(u_{*}^{2}-u_{* t}^{2}\right)
$$

where $\mathrm{F}$ is the vertical mass flux of dust that is obtained from the friction velocity $u_{*}$, a threshold friction velocity $\mathrm{u}_{* t}$, (required for initiation of dust emission), and a coefficient $K(\mathrm{~s} / \mathrm{m})$ that depends on the surface soil texture. The friction velocity varies in space and time. However, the threshold velocity and soil texture coefficient vary only in space and related to the soil, land-use characteristics and surface roughness. In this study, the model is used over domain where detailed soil characteristics are not available and revised version of the dust module for vertical mass flux is replaced as Equation (1) [29].

$$
F=0.01 u_{*}^{4}
$$

Table 3 Dust hotspots resulted by HYSPLIT dust module

\begin{tabular}{cccc}
\hline $\begin{array}{c}\text { May event } \\
\text { hotspots }\end{array}$ & $\begin{array}{c}\left(\mathbf{3 2 . 5 0}{ }^{\circ} \mathrm{N},\right. \\
\left.\mathbf{3 8 . 0 0}{ }^{\circ} \mathrm{E}\right)\end{array}$ & $\begin{array}{c}\left(\mathbf{3 3 . 8 0}{ }^{\circ} \mathrm{N},\right. \\
\left.\mathbf{3 8 . 3 0}{ }^{\circ} \mathrm{E}\right)\end{array}$ & $\begin{array}{c}\left(\mathbf{3 2 . 5 0}{ }^{\circ} \mathbf{N},\right. \\
\left.\mathbf{3 8 . 2 5}{ }^{\circ} \mathrm{E}\right)\end{array}$ \\
\hline $\begin{array}{c}\text { June event } \\
\text { hotspots }\end{array}$ & $\left(33.75^{\circ} \mathrm{N}, 38.25^{\circ} \mathrm{E}\right)$ & $\left(33.75^{\circ} \mathrm{N}, 38.80^{\circ} \mathrm{E}\right)$ & - \\
\hline
\end{tabular}



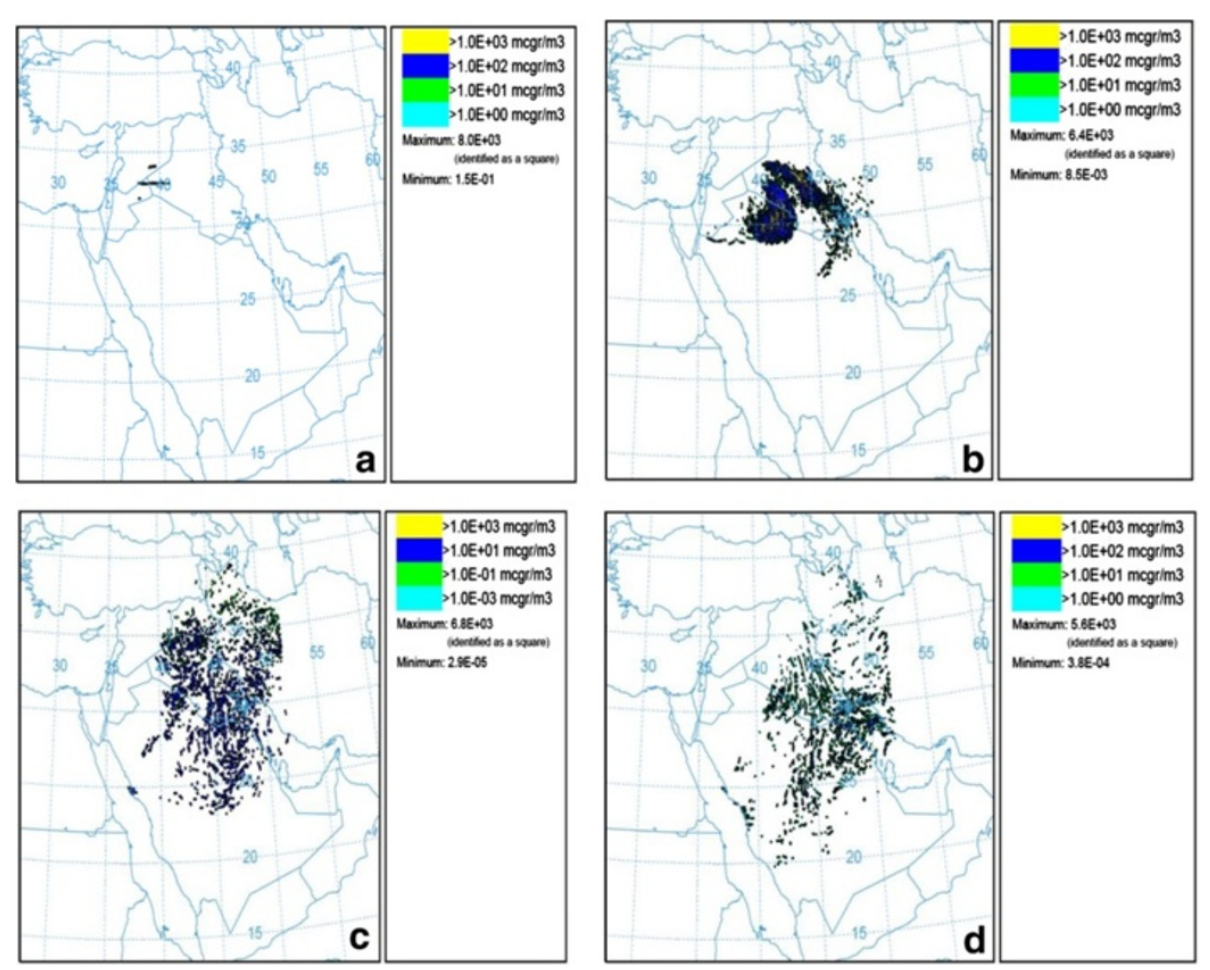

Figure 4 Modeling results for concentration PM10 of averaged 0 - 100 m in May, (a) 17, (b) 18, (c) 19 and (d) 20 May.
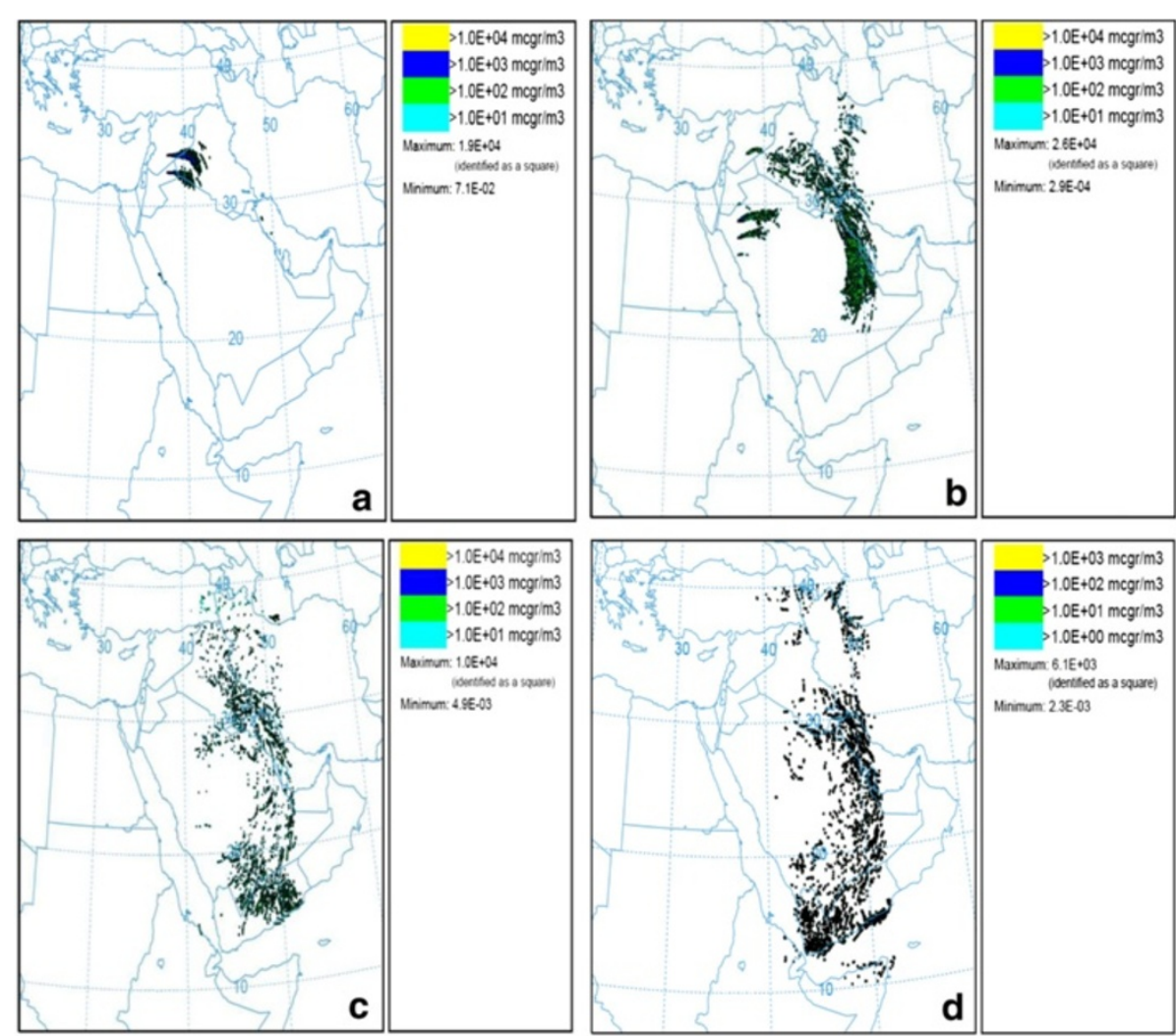

Figure 5 Modeling results for concentration of PM10 averaged 0 - $100 \mathrm{~m}$ in June, (a) 7, (b) 8, (c) 9 and (d) 10 June. 
Based on these algorithms $\mathrm{PM}_{10}$ is emitted from desert land-use, when the wind velocity exceeds from local friction velocity and this parameter is defined as:

$$
U_{t}=\frac{u_{* t}}{k} \ln \frac{z}{z_{0 n s}}
$$

Where $z_{\text {Ons }}$ is the aerodynamic roughness length for nonsaltating conditions, $\mathrm{z}$ is the wind measurement height and Von Karman's constant $k$ is assumed to be 0.4 [17].

In this research, dispersion simulation is done over the study area with HYSPLIT dust module. A horizontal domain of $30^{\circ} \times 30^{\circ}$ with resolution of $0.05^{\circ} \times 0.05^{\circ}$ and a vertical level of 100 meters above ground level is considered in dispersion model. Pollutant concentrations are sampled in every time step and are averaged over every $12 \mathrm{~h}$. The turbulence mixing is computed using a diffusivity approach based on vertical stability estimates and the horizontal wind field deformation. The puff dispersion is assumed to be linear function of time. Ground level concentrations are calculated as average of the lowest $100 \mathrm{~m}$ within each horizontal grid cell. HYSPLIT dust storm modeling done for $0.25^{\circ} \times 0.25^{\circ}$ resolution for desert dust sources and a total of 100,000 particles or puffs are released during one release cycle with a maximum of 50,000 particles permitted to be carried at any time during the simulation. Release mode is sampled with 3-dimensional (3-D) particle horizontal and vertical option.

The trajectory calculation in any Lagrangian model is based on the following the particle or puff. Therefore, once the basic meteorological data $(\mathrm{U}, \mathrm{V}$ and $\mathrm{W})$ has been processed and interpolated to the model grid. Trajectories can be computed to test the advection components of the model. The advection is computed from the average of the 3-D velocity vectors for the initialposition $\mathrm{P}(\mathrm{t})$ and the first-guess position $\mathrm{P}^{\prime}(\mathrm{t}+\Delta \mathrm{t})$. The

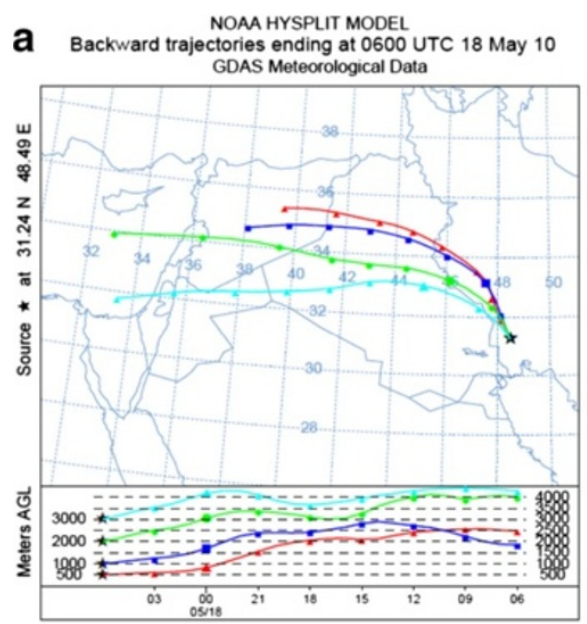

NOAA HYSPLIT MODEL
C Backward trajectories ending at 1200 UTC 08 Jun 10 GDAS Meteorological Data

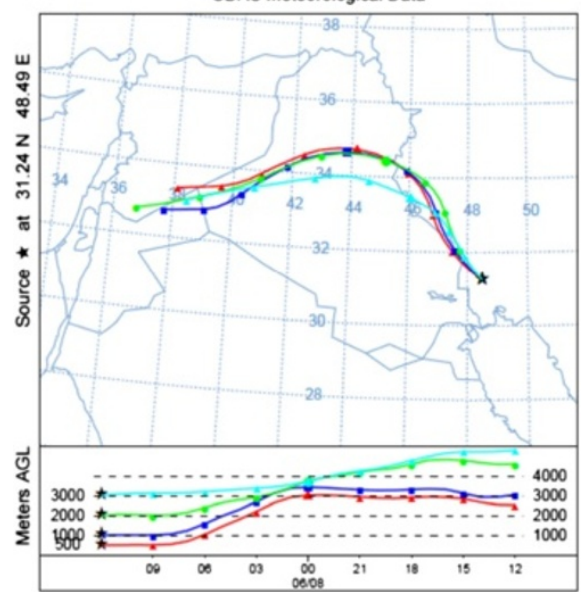

Figure 6 HYSPLIT Back trajectory simulations. (a) Ahvaz on May 18th
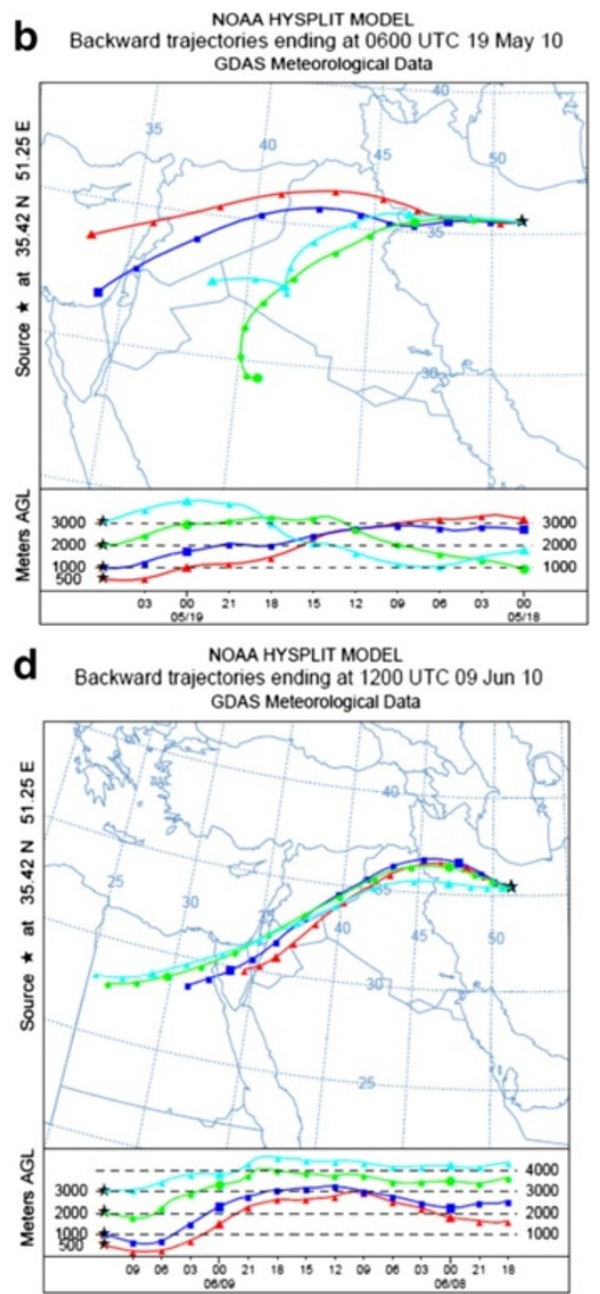

(b) Tehran on May 19th, (c) Ahvaz on June 8th, (d) Tehran on June 9th. 
velocity vectors are linearly interpolated in both space and time $[25,26]$.

The first guess position is

$$
\mathrm{P}^{\prime}(\mathrm{t}+\Delta \mathrm{t})=\mathrm{P}(\mathrm{t})+\mathrm{V}(\mathrm{P}, \mathrm{t}) \Delta \mathrm{t}
$$

and the final position is

$$
\mathrm{P}(\mathrm{t}+\Delta \mathrm{t})=\mathrm{P}(\mathrm{t})+0.5\left[\mathrm{~V}(\mathrm{P}, \mathrm{t})+\mathrm{V}\left(\mathrm{P}^{\prime}, \mathrm{t}+\Delta \mathrm{t}\right)\right] \Delta \mathrm{t}
$$

In this study back trajectory simulations were used for determining source of dust storms and motion direction of dust plume over Middle East and Iran. Back trajectories started from Ahvaz $\left(31.24{ }^{\circ} \mathrm{N}, 48.49^{\circ} \mathrm{E}\right)$ and Tehran $\left(35.42^{\circ} \mathrm{N}, 51.25^{\circ} \mathrm{E}\right)$ at the time of dust arrival. For HYSPLIT trajectory setting, four trajectory tracking levels including 500, 1000, 2000 and $3000 \mathrm{~m}$ are considered and also the top of model assumed to be $10,000 \mathrm{~m}$.

Turbulence, wind fields and mixing depth values are used as inputs for dispersion model.

\section{Results and discussion}

First, the meteorological parameters surveyed in desert areas and the results showed that high wind velocity and mixing height caused to inject and lift the dust to the atmosphere, respectively. Second, dust hotspots determined in Syrian deserts and motion of dust simulated over study area using meteorological fields. The results are discussed in details as follows.

Two case studies are simulated in this research. These dust storms occurred on May $17^{\text {th }}-20^{\text {th }}$ and June $7^{\text {th }}-10^{\text {th }}, 2010$. In these two periods of time, $\mathrm{PM}_{10}$ concentration dramatically exceeded the ambient air quality standards $\left(50 \frac{\mu g}{m^{3}}\right)$. Table 1 Shows $\mathrm{PM}_{10}$ concentrations in three air quality stations of Ahvaz during these periods [30].

\section{Meteorogical fields}

Meteorological fields and flow patterns are analyzed in the 3-D model grid. Meteorological simulation indicates the development of diurnally varying local flow pattern. The wind fields at $10 \mathrm{~m}$ above the ground surface at 9 UTC on May $17^{\text {th }}$ (a) and 12 UTC on June $7^{\text {th }} 2010$ (b) are shown in Figure 3. As illustrated in the figure, the main flow pattern was westerly and northwesterly in dust region around midday. This pattern rarely changed in the course of the day.

Table 2 shows the case studies' meteorological parameters in dust hotspots area at the time of injection. As
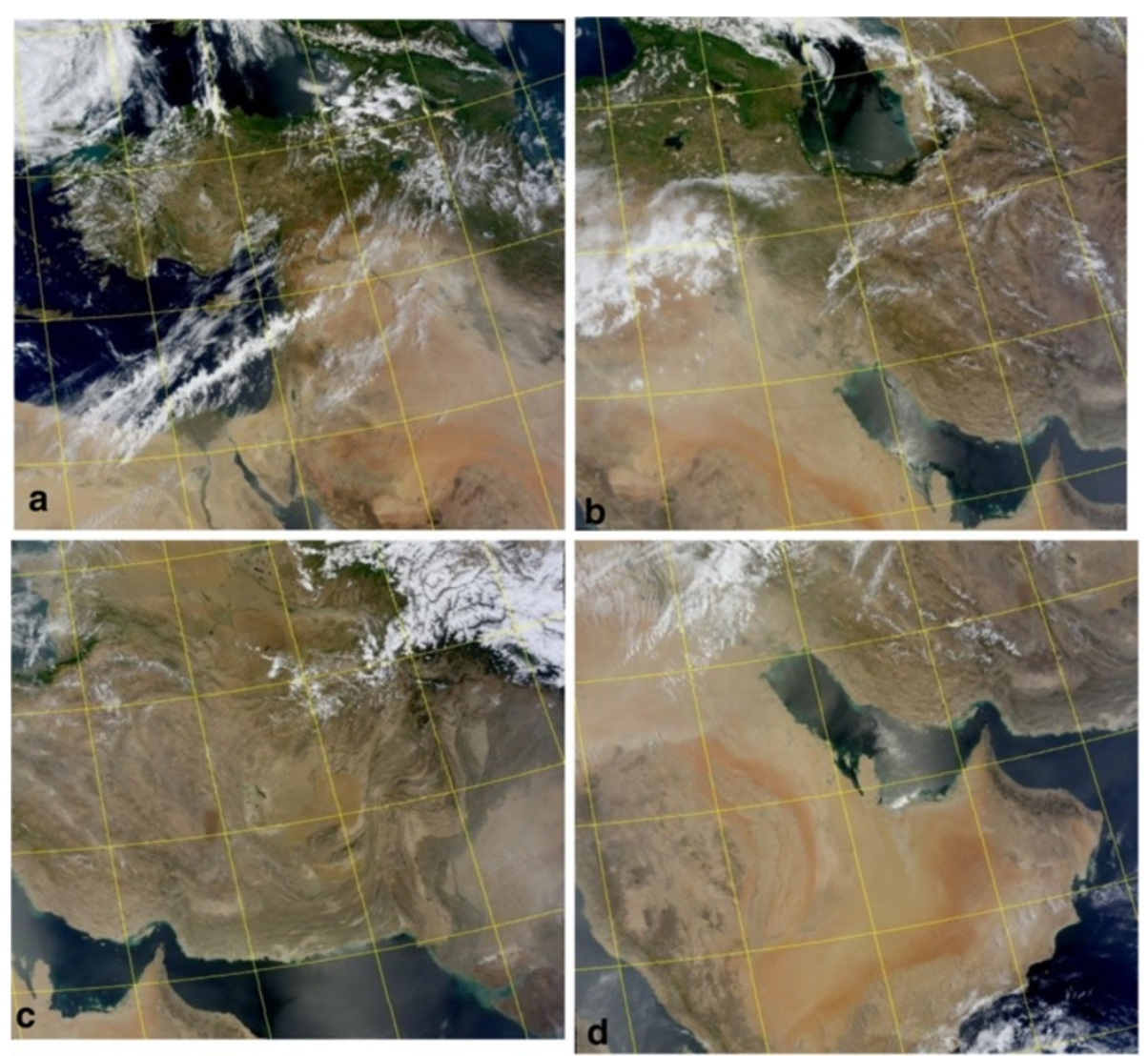

Figure 7 MODIS satellite images for May dust storm. (a) 17, (b) 18, (c) 19 and (d) 20 May. 
indicated in Table 2, these parameters are approximately similar in two assessed dust events. The wind speed is the most important parameter that influences particulate matter advection and dispersion and planetary boundary layer height (PBLH) Causes particulates dispersing in vertical direction. In these events PBLH was above 2000 $\mathrm{m}$ and dust dispersed effectively in vertical direction.

\section{Dust module modeling results}

May dust event was started at about 9 UTC on May 17th from west of syrian desert and dust injected for about 15 hours. Main hotspots derived by model for case studies are shown in Table 3. Dust plume spreaded in northwesterly direction and reached to Ahvaz in noontime of May 18 and increased $\mathrm{PM}_{10}$ concentration in the city to $496 \frac{\mu g}{m^{3}}$ reported by DOE. Dust storm reached to Tehran on May 19th at 6 UTC and air quality of Tehran drastically was affected by air borne particles. The avarege of $\mathrm{PM}_{10}$ concentration of Tehran was $343 \frac{\mu g}{m^{3}}$.

In the second case study, when wind speed exceeded $10.34 \mathrm{~m} / \mathrm{s}$ in Syrian Desert (Syria and Jordan region) at 12 UTC on June 7th, dust storm started and dust emitted for about 12 hours. This event affected western part of Iran, especially Khuzestan province. Dust plumes reached to Ahvaz at the beginning of the June 8th. The average of $\mathrm{PM}_{10}$ concentration reached to $625 \frac{\mu g}{m^{3}}$ in the Ahvaz monitoring stations during the day. Figures 4 and 5 show results of dust storm modeling for May (17 May (a), 18 May (b), 19 May (c) and 20 May (d)) and June (7 June (a), 8 June (b), 9 June (c) and 10 June (d)) dust events, respectively.

\section{Trajectory results}

In this research, Horizontal and vertical pathways of dust parcel are simulated using trajectory approach. For May dust event, according to the arrival time of dust storms to Ahvaz and Tehran, back trajectory simulation started at 6 UTC on May 18th for Ahvaz and 6 UTC on May 19th for Tehran. The source of dust storm was located in west and north of Syrian Desert. Trajectory simulation began at 12 UTC on June 8th for Ahvaz and 12 UTC on June 9th for Tehran for June case study. This trajectory modeling showed that Source of early June dust storm was in western Syrian Desert and near the border of Syria, Jordan and Saudi Arabia. Figure 6 shows backward trajectory plots of Tehran and Ahvaz (Ahvaz at 6 UTC 18 May (a), Tehran at 6 UTC 19 May
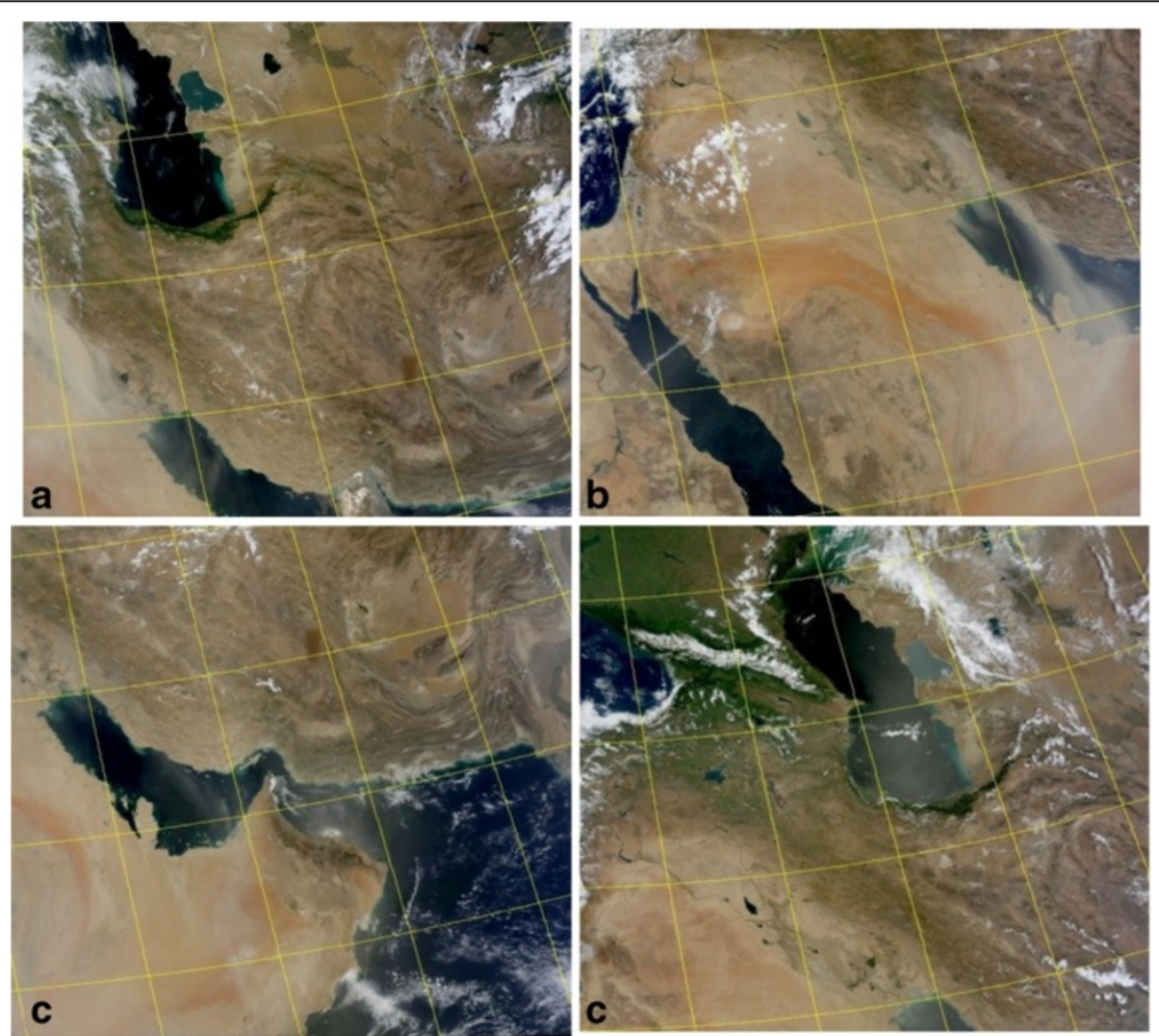

Figure 8 MODIS satellite images for June dust storm. (a) 7, (b) 8, (c) 9 and (d) 10 June. 
(b), Ahvaz at 12 UTC 08 June (c) and Tehran at 12 UTC 09 June (d)).

In the first case in May, studying arrival altitudes in Tehran and Ahvaz indicates that vertical distribution of dust in Tehran was 1000 and in Ahvaz was about 2000$3000 \mathrm{~m}$. in the second case in June; height of dust plume was up to $2000 \mathrm{~m}$ above ground surface.

For supporting HYSPLIT results, MODIS ${ }^{\mathrm{f}}$ satellite images have been used in this study. MODIS plays a significant role on earth observations of dust events which can identify dust storms using optical satellite images based on the radiation and scattering characteristics of particles. Temporal and spatial coverage computed by HYSPLIT was significantly similar to MODIS images. Figures 7 and 8 demonstrate MODIS images for case studies over study area provided by NASA rapid response imagery [31].

According to Figure 7, on May $17^{\text {th }}$, dust appeared in Syria and after passing over Iraq gradually moved to the western and central parts of Iran. Also Figure 8 shows that dust storm on June 7th after covering large regions of Iraq reached Khuzestan province and finally circulated towards the Persian Gulf and Arabian Peninsula.

In this study, MODIS images confirmed the results of HYSPLIT dust modeling and it was detected that dust plumes had a circulating motion while moving towards eastern parts of Middle East.

\section{Conclusion}

In this research source identification and trajectory simulation of two dust storms over Iran which was caused by wind erosion are studied. The HYSPLIT model dust module was applied to a western Middle East deserts. However, the results clarified that both of dust events simulated started from Syrian Desert in similar coordinates. Due to the high shear wind speed and mixing height, dust was released from desert landuse and dispersed horizontally and vertically over the study area. In addition, strong winds transported the dust through large areas of Iraq and Kuwait reaching the significant parts of Iran in about 48 hours. Backward trajectory simulation from Tehran and Ahvaz confirmed dust sources derived by dust module. At end, dust motion in MODIS images were compared to the output of HYSPLIT simulation which showed same trends.

\section{Endnotes}

${ }^{a}$ Scanning Imaging Absorption Spectro-Meter for Atmospheric Cartography

${ }^{\mathrm{b}}$ Hybrid Single-Particle Lagrangian Integrated Trajectory

${ }^{\mathrm{c}}$ Global Data Assimilation System

${ }^{\mathrm{d}}$ Zonal component of wind

${ }^{\mathrm{e}}$ Meridional component of wind

${ }^{\mathrm{f}}$ Moderate Resolution Imaging Spectro radiometer
Competing interests

The authors declare that no conflict of interest.

\section{Authors' contributions}

All authors read and approved the final manuscript.

\section{Acknowledgments}

The authors gratefully acknowledge the technical support provided by Dr. Majid Azadi (Atmospheric Science and Meteorological Research Center) and Mr. Hossein Vahidi (Academic Center for Education, Culture and Research).

\section{Author details}

'Graduate Faculty of Environment, University of Tehran, Tehran, Iran. ${ }^{2}$ Institute of Geophysics, University of Tehran, Tehran, Iran.

Received: 9 August 2012 Accepted: 15 October 2013

Published: 7 January 2014

\section{References}

1. Wen Kuoa H, Yi Shena H: Indoor and outdoor PM2.5 and PM10 concentrations in the air during a dust storm. Build Environ 2010, 3(45):610-614

2. Shao Y: Physics and Modeling of Wind Erosion. Germany: Springer Press; 2008. ISBN ISBN 978-1-4020-88

3. Prospero M, Ginoux P, Torres O, Nicholson E, Gill E: Environmental characterization of global source of atmospheric soil dust identified with the nimbus 7 total ozone mapping Spectrometer (TOMS) absorbing aerosol product. J Geophys Res 2002, 40(1):1-31.

4. Escudero M, Stein A, Draxler R, Querol X, Alastuey A, Castillo S: Determination of the contribution of north Africa dust source areas to PM10 concentrations over the central Iberian peninsula using the hybrid single-particle lagrangian integrated trajectory model (HYSPLIT) model. J Geophys Res 2006(111):D06210. DOl: 10.1029/2005JD006395.

5. de Graaf M: Remote Sensing of UV-absorbing aerosols using space-borne spectrometers, Ph.D Thesis. Amsterdam: Vrije Universiteit Amsterdam; 2006:132.

6. Gerivani H, Lashkaripour G, Ghafoori M, Jalali N: The source of dust storm in Iran: a case study based on geological information and rainfall data. Carpathian J Earth Environ Sci 2003, 6(1):297-308.

7. Shinn EA, Smith GW, Prospero JM, Betzer P, Hayes ML, Garrison V, Barber RT: African dust and the demise of Caribbean coral reefs. Geophys Res Lett 2001, 27(19):3029-3032.

8. Wang Y, Zhuang G, Tang A, Zhan W, Sun Y, Wang Z, An Z: The evolution of chemical components of aerosols at five monitoring site of China during dust storms. Atmos Environ 2007, 41:1091-1106.

9. McKendry G, Hacker P, Stull R, Sakiyama S, Mignacca D, Reid K: Long-range transport of Asian dust to the lower Fraser valley, British Columbia, Canada. J Geophys Res 2001, 106:18,361-18,370.

10. Chan Y, McTainsh G, Leys J, McGowan H, Tews K: Influence of the 23 October 2002 dust storm on the air quality of four Australian cities. Water Air Soil Pollut 2005, 164:329-348.

11. Griffin D, Kellogg C: Dust storms and their impact on ocean and human health: dust in Earth's atmosphere. Ecohealth 2004, 1:284-295.

12. Dickerson R, Kondragunta S, Stenchikov G, Civerolo K, Doddridge B, Holben $\mathrm{B}$ : The impact of aerosols on solar ultraviolet radiation and photochemical smog. Science 1997, 278:827-830.

13. Alastuey A, Querol X, Castillo S, Escudero M, Avila A, Cuevas E, Torres C, Romero PM, Exposito F, Garcia O, Diaz JP, Dingenen RV, Putaud JP: Characterization of TSP and PM2.5 At izanea and Sta. Cruz de Tenerife (canary islands, Spain) during a Saharan dust episode (July 2002). Atmos Environ 2005, 39(26):4715-4728.

14. IPCC: Fourth Assessment Report of the Intergovernmental Panel on Climate Change. Working Group I: the Physical Science Basis of Climate Change. Summary for Policymakers. Geneva, Switzerland: Intergovernmental Panel on Climate Change; 2007.

15. Miller RL, Tegen I: Climate response to soil dust aerosols. J Clim 1998, 11:3247-3267.

16. Gao Y, Fan S, Sariento JL: Aeolian iron input to the ocean through precipitation scavenging: a modelling perspective and its implications for natural iron fertilization in the ocean. J Geophys Res 2003, 108(7):4221. 
17. Draxler R, Gillette A, Kirkpatrick S, Heller J: Estimating PM10 air concentrations from dust storms in Iraq, Kuwait and Saudi Arabia. Atmos Environ 2001, 35:4315-4330.

18. Xuan J: Emission inventory of eight elements, $\mathrm{Fe}, \mathrm{Al}, \mathrm{K}, \mathrm{Mg}, \mathrm{Mn}, \mathrm{Na}, \mathrm{Ca}$ and $\mathrm{Ti}$, in dust source region of East Asia. Atmos Environ 2005, 39:813-821.

19. Wang W, Fang ZY: Numerical simulation and synoptic analysis of dust emission and transport in East Asia. Glob Planet Chang 2006, 52:57-70.

20. Alam K, Qureshi S, Blaschke T: Monitoring Spatio-temporal aerosol patterns over Pakistan based on MODIS, TOMS and MISR satellite data and a HYSPLIT model. Atmos Environ 2011, 45:4641-4651.

21. Givehchi R, Arhami M, Tajishy M: Contribution of the middle eastern dust source areas to PM10 levels in urban receptors: case study of Tehran, Iran. Atmos Environ 2013, 75:287-295.

22. Zolfaghari $\mathrm{H}$, Abedzadeh $\mathrm{H}$ : Synoptic analysis of dust sources in west of Iran. Journal of Geography and Development 2005, 3(6):173-188 (in Persian).

23. Iranmanesh F, Akram M: Survey on sources areas and characteristics of dust storms dispersion in sistan region using satellite imagery processing. Construction and research journal 2003, 67:104. (in Persian).

24. WHO: Urban Outdoor air Pollution Database. Department of Public Health and Environment. Geneva, Switzerland: World Health Organization; 2011. http://www.who.int/phe/health_topics/outdoorair/databases/OAP_database. xls.

25. Draxler R, Hess GD: An overview of the HYSPLIT_4 modeling system for trajectories, dispersion and deposition. Aust Meteorol Mag 1998, 47:295-308.

26. Draxler R, Stunder B, Rolph G, Stein A, Taylor A: Hybrid Single-Particle Lagrangian Integrated. United States: NOAA; 2009.

27. Challa VS, Indrcanti J, Baham JM, Patrick C, Rabarison MK, Young JH, Hughes R, Swanier SJ, Hardy MG: Sensitivity of atmospheric dispersion simulations by HYSPLIT to the meteorological predictions from a meso-scale model. Environ Fluid Mech 2008, 8(4):387-367. trajectories 4 user's guide. NOAA Tech. Memo, ERL-ARL.

28. Marticorena B, Bergametti G, Gillette D, Belnap J: Factors controlling threshold friction velocity in semiarid and arid areas of the United States. J Geophys Res 1997, 102:23,277-23,287.

29. Westphal L, Toon OB, Carlson TN: A two-dimensional numerical investigation of the dynamics and microphysics of Saharan dust storms. J Geophys Res 1987, 92(3):3027-3049.

30. IR.DOE data: Ahvaz air Pollution Monitoring Stations Datasets. Tehran, Iran: Department of Environment; 2011.

31. MODIS rapid response: Satellite Images. 2010 http://rapidfire.sci.gsfc.nasa. gov/realtime/2010158/.

doi:10.1186/2052-336X-12-9

Cite this article as: Ashrafi et al:: Dust storm simulation over Iran using HYSPLIT. Journal of Environmental Health Science and Engineering 2014 12:9.

\section{Submit your next manuscript to BioMed Central and take full advantage of:}

- Convenient online submission

- Thorough peer review

- No space constraints or color figure charges

- Immediate publication on acceptance

- Inclusion in PubMed, CAS, Scopus and Google Scholar

- Research which is freely available for redistribution 